\title{
Leprosy situation in South Sulawesi, Indonesia
}

\section{Sri Vitayani MUCHTAR ${ }^{1,3}$, Yoshiko YANAGIDA ${ }^{2}$, Masami ENDOH ${ }^{3}$ and Yasuko YOGI ${ }^{3}$}

Since the World Health Organization (WHO) set the global goal of leprosy elimination in 2000, many countries have successfully achieved elimination. Indonesia has achieved elimination at a national level, but several provinces and areas still have a high prevalence rate. South Sulawesi is one of 6 provinces on Sulawesi Island, and 5 of these provinces still have many leprosy patients with a prevalence rate of more than 1.1 per 10,000 population and new cases are detected every year. The leprosy control program has not been successful in reducing the prevalence of this disease and 22 out of 27 regencies have, on average, a prevalence rate of 2.3 cases per 10,000 population, of which child cases account for more than $5 \%$, indicating that there are many more leprosy cases in the community. The leprosy control program has been helped by the multi drug therapy (MDT) regimen based on the WHO recommendation and several research studies carried out in the area. However, we as yet do not have a clear idea how to eliminate leprosy in South Sulawesi and further research is required.

Key words : leprosy, South Sulawesi, Indonesia, leprosy control program

\section{Introduction}

Leprosy is still a major disease worldwide (World Health Organizations, 1999) and Indonesia is one country that has a large number of leprosy patients. Indonesia's 7,000 islands spread across the Indonesian ocean are home to more than 300 ethnic groups. To tackle health problems, the government has posted doctors and nurses or health workers to hospitals and primary health centers (puskesmas) in the regencies and some villages. Leprosy is one of the communicable diseases that must be dealt with by health workers, and at the present time the number of leprosy patients is high and there has been no decrease in prevalence (Departemen Kesehatan Republik Indonesia, 2001 ; Departemen Kesehatan Republik Indonesia,
2005)

We do not have the answer for how and why this situation occurs. Even though Indonesia has a good policy of leprosy control, prevalence has not decreased. Here, we describe the leprosy situation in South Sulawesi and discuss its epidemiology, treatment and the leprosy control program in place.

\section{Epidemiological situation of leprosy}

The World Health Organization (WHO) defined leprosy elimination in 2000 to be a prevalence rate of $<1$ case per 10,000 population (World Health Organizations, 1999), and Indonesia has already accomplished this at the national level ( 0.93 cases per 10,000 population). However, the prevalence rate remains high in the provinces, even at the district level. In the case of children, the program has

\footnotetext{
${ }^{1}$ Medical Faculty, Indonesian Moslem University

${ }^{2}$ School of Health and Sports Science, Juntendo University

${ }^{3}$ Leprosy Research Center, National Institute of Infectious Diseases
} 
Table 1 The situation of leprosy cases in South Sulawesi

\begin{tabular}{ccccc}
\hline Year & $\begin{array}{c}\text { Prevalence } \\
\text { rate } \\
/ 10,000\end{array}$ & $\begin{array}{c}\text { NCDR (New case } \\
\text { Detection rate }) \\
/ 100,000\end{array}$ & $\begin{array}{c}\text { Proportion of } \\
\text { disability } \\
(\%)\end{array}$ & $\begin{array}{c}\text { Children } \\
\text { cases } \\
(\%)\end{array}$ \\
\hline 2001 & 2.2 & 22.0 & 9.0 & 9.0 \\
\hline 2002 & 2.2 & 23.6 & 7.1 & 8.2 \\
\hline 2003 & 2.0 & 19.8 & 7.4 & 6.4 \\
\hline 2004 & 2.02 & 21.2 & 6.8 & 6.0 \\
\hline 2005 & 2.3 & 22.3 & 7.8 & 6.0 \\
\hline
\end{tabular}

Source : South Sulawesi Health Department in reference 4.

Table 2 The regencies that having a lot of leprosy patients (endemic areas)

\begin{tabular}{lc}
\hline Name of regencies & Prevalence rate/10,000 \\
\hline Polmas & 4.3 \\
\hline Soppeng & 3.6 \\
\hline Majene & 3.5 \\
\hline Jeneponto & 3.4 \\
\hline Sinjai & 3.3 \\
\hline Barru & 3.3 \\
\hline Wajo & 3.3 \\
\hline Bulukumba & 3.1 \\
\hline Bone & 3.1 \\
\hline Pare-pare & 3.0 \\
\hline Takalar & 2.7 \\
\hline Gowa & 2.3 \\
\hline
\end{tabular}

Source : South Sulawesi Health Department in reference 4.

created a motion to maintain the occurrence rate of child leprosy patients in relation to new case detection rate (NCDR) and proportion of disability at $5 \%$. However, this has not been achieved to date (see Table 1 ). Until this year, there are 12 provinces and 140 out of 424 regencies in Indonesia that still have many leprosy patients. Moreover, every year many new cases are detected by the leprosy control program, which raises the question of how to eliminate this disease (Departemen Kesehatan Republik Indonesia, 2001 ; Departemen
Kesehatan Republik Indonesia, 2005).

Speciality in leprosy in South Sulawesi. The South Sulawesi province has 27 regencies with a population of $8,261,100$, made up of 4 major ethnic groups ; Makassar, Bugis, Mandar and Toraja. As in other provinces, South Sulawesi has some hospitals and primary health centers (puskesmas) with a doctor, nurses and health workers. South Sulawesi is one of the 12 provinces that still have a high prevalence rate. Despite the leprosy control program and a leprosy training center here that provides training to healthcare workers from across Indonesia, the number of leprosy cases has not decreased and the disease remains a public health problem (Departemen Kesehatan Republik Indonesia, 2001 ; Departemen Kesehatan Republik Indonesia, 2005).

Epidemiology in South Sulawesi. The WHO leprosy elimination campaign was established in 2,000 . However, South Sulawesi has not yet achieved elimination, as shown in Tables 1, 2 and 3 , since many regencies, districts and villages have high prevalence (Departemen Kesehatan Republik Indonesia, 2005 ; Dinas Kesehatan Propinsi Sulawesi Selatan, 2005). South Sulawesi had 1,772 leprosy patients in 2001 , with a prevalence rate of 2.2 cases per 10,000 population, and the situation is largely unchanged (Table 1). The number of leprosy patients is high and new patients are detected 
Table 3 The new case that finding by leprosy control program

\begin{tabular}{cccc}
\hline Year & Num. of patients & PB type & MB type \\
\hline 2001 & 1,772 & 506 & 1,266 \\
\hline 2002 & 1,947 & 549 & 1,398 \\
\hline 2003 & 1,526 & 404 & 1,122 \\
\hline 2004 & 1,672 & 423 & 1,249 \\
\hline 2005 & 1,802 & 442 & 1,360 \\
\hline
\end{tabular}

Source : South Sulawesi Health Department in reference 4.

every year. In 2005, the number of registered patients was 1,886 , with 1,802 new patients detected and an NCDR of 22.3 cases per 100,000 population (Table 1 and 3 ). The prevalence rate of $<1$ case per 10,000 population was achieved in only 5 out of 27 regencies (Table 2) (Dinas Kesehatan Propinsi Sulawesi Selatan, 2005). In addition, the ratio of Multibacillary (MB) type, which is the infectious source of leprosy, to Paucibacillary (PB) type was $3: 1$ or more (Table 3 ). Many new cases of leprosy have been found in Jeneponto and Majene, and the number of patients with disability among new cases was high in Wajo and Enrekang (4). Many child cases of leprosy are found in Jeneponto and Gowa (Departemen Kesehatan Republik Indonesia, 2005; Dinas Kesehatan Propinsi Sulawesi Selatan, 2005).

Leprosy control program. The management of leprosy was introduced to Indonesia in 1928 by Dr. Sitanala, and leprosy control that started in Java and Bali gradually extended to other provinces with the assistance of WHO and UNICEF (Louhenapessy, 1979).

In 1981, WHO recommended treatment of leprosy with drug combinations, called multi drug therapy (MDT). Indonesia, including South Sulawesi, started to use MDT in 1982 (World Health Organizations, 1999 ; Departemen Kesehatan Republik Indonesia, 2001). The program's policy consists of the following 4 actions for leprosy patients (Departemen Kesehatan Republik Indonesia, 2001 ; Departemen Kesehatan Republik Indonesia, 2005 ; Dinas Kesehatan Propinsi Sulawesi Selatan, 2005).

\section{Case detection}

Early case detection is vital to prevent the transmission of leprosy bacilli in the community. Health centers in all areas of the country work hard to achieve early detection as some people still have leprosy stigma. Sometimes surveys are made of the area to detect leprosy patients, because in some cases the family hides the patients (Schreuder et al., 2002).

\section{Treatment}

The doctor, nurses or leprosy workers must check that the patient visits the healthcare facility each month to receive MDT. When the patient does not visit, the leprosy workers or nurses must deliver the drug to the patient.

\section{Community health education}

The policy is to teach everyone in the community that one white macula is a sign of leprosy and what they should do on finding such a sign. Such campaigns must be finished in all areas covered by the health center by the end of the year. 
4. Regular training regularly for leprosy workers and professional staff

South Sulawesi province has a leprosy training center (PLKN) that trains doctors and leprosy workers from puskesmas across Indonesia. The training provides knowledge about leprosy and teaches many relevant practices about how to take and read a skin smear, examine for nerve damage, manage leprosy campaigns, make a leprosy diagnosis, treat leprosy patients and leprosy reaction among other problems. The participants than must teach the patient and family how to carry out self care at home (Departemen Kesehatan Republik Indonesia, 2001 ; Pusat Pelatihan Kusta Nasional, 2004). After training, the participants will visit a leprosy program at hospitals or puskesmas in order to see a good leprosy control program in action (Pusat Pelatihan Kusta Nasional, 2004).

\section{Treatment of leprosy}

In 1982, WHO made recommendations that the treatment of leprosy patients be carried out by MDT that included rifampin $600 \mathrm{mg}$ monthly, dapsone $100 \mathrm{mg}$ daily and clofazimine $300 \mathrm{mg}$ monthly and then $50 \mathrm{mg}$ daily; $\mathrm{PB}$ type requires rifampin and dapsone for 6 months, and MB type all three drugs for 12 months (World Health Organizations, 1999 ; Departemen Kesehatan Republik Indonesia, 2001 ; Departemen Kesehatan Republik Indonesia, 2005). Sometimes, in severe cases, reaction may occur before, during and after MDT treatment. Leprosy reaction is one of the major problems faced by leprosy patients and the leprosy control program's policy involves the administration of analgetic and antipyretic analgesics for reversal reaction without neuritis (type 1 reaction). Alternatively, prednisone is administered for reversal reaction with neuritis (type 1) and for erythema nodosum leprosum (ENL) of type 2 reaction. Prednisone is started from $40 \mathrm{mg}$ every morning and is gradu- ally reduced every 2 weeks by $10 \mathrm{mg}$ over a $6^{-}$ week period and thereafter by $5 \mathrm{mg}$ over an additional 6-week period (12 weeks in total). A return to the previous dose must be made if the skin lesion worsens under the administration. When we find such prednisone-dependent patients, we provide a 3-month treatment course of incremental doses of clofazimine as recommended by the leprosy control program, and we then finally return to the MDT doses (Departemen Kesehatan Republik Indonesia, 2001 ; Departemen Kesehatan Republik Indonesia, 2005). However, South Sulawesi has an alternative treatment ROM or modified Quadruple Therapy.. When the patient complains of, for example, skin discoloration, it is possible to administer ROM by changing the MDT when approved by a dermatologist at a leprosy hospital (Dhople, 2000 ; Muchtar et al., 2005). The leprosy hospital is exempt from all costs related to hospitalization (Dinas Kesehatan Propinsi Sulawesi Selatan, 2005). Under the leprosy control program in South Sulawesi, treatment is carried out with the cooperation of a dermatologist when the leprosy patient suffers from symptoms such as leprosy reaction (Pusat Pelatihan Kusta Nasional, 2004), Dapsone syndrome (drug allergy with dapsone) (Jacobson, 1994) or neuropathic pain (Hietaharju et al., 2000 ; Haanpaa et al., 2004).

Ulcers and disability create different problems for leprosy patients. In these cases, it is very important to understand and learn how the patients and family provide for self-care at home. Management mainly depends on the support of the patient for their self care (Departemen Kesehatan Republik Indonesia, 2001 ; Muchtar et al., 2005). Disability, especially claw hand with a duration of $<$ 6 months, can be treated by physiotherapy and prednisone of $30 \mathrm{mg}$ to $40 \mathrm{mg}$ daily, with dose reduction depending on improvement (Departemen Kesehatan Republik Indonesia, 2001 ; Pusat Pelati- 
han Kusta Nasional, 2004). Over 50\% of leprosy patients have ulceration of the foot in South Sulawesi. The leprosy program offers equipment for self-care such as shoes, sandals, and a bicycle to help such patients. However, many patients do not use them because it is their custom to walk barefoot. In the event of severe ulceration, the leprosy control program must sometimes send the patient to a leprosy hospital for care and treatment, which may involve long-term care (Departemen Kesehatan Republik Indonesia, 2001 ; Pusat Pelatihan Kusta Nasional, 2004).

\section{Research in leprosy}

An investigation of the epidemiology and transmission of leprosy was conducted in South Sulawesi (Van Beers et al., 1994 ; Bakkeret al., 2002), and included genetic factors (Bakker et al., 2005a) and prevention (Bakker et al., 2005b), but we still do not have a clear picture of how we can eliminate this disease. Hatta's research among children suggested that the prevalence of antibodies in children may be indicative of the active transmission of M. leprae in their surroundings (Hatta, 2003). Recently, we examined and reported M. lepraespecific phenolic glycolipid-1 (PGL-1) antibody in the serum of 20 families with child leprosy using the M. leprae-simple gelatin particle aggulutination (MLPA) test, finding the result of the test was high among children and, surprisingly, among their families also (Muchtar et al., 2006). We are now investigating how and why such leprosy cases arise.

Much more time is needed for leprosy elimination in South Sulawesi, Indonesia.

\section{Reference}

Bakker IM, Hatta M, Kwenang A et al. (2002) : Epidemiology of leprosy on five island in the Flores Sea, Indonesia, Trop Med Int Health, 7(9), 780-787
Bakker IM, May L, Hatta M et al. (2005a) : Genetic, household and spatial clustering of leprosy on an island in Indonesia : a population based study, BMC Med genetic, 6(40), 1471-2350

Bakker IM, Hatta M, Kwenang A et al. (2005b) : Prevention of leprosy using rifampicin as chemoprophylaxis, Am J Trop Med Hyg, 72 (4), 443-448

Departemen Kesehatan Republik Indonesia (2001) : Buku Pedoman Pemberantasan Penyakit Kusta, DitJen PPM \& PPLP. Dep Kes RI, Jakarta)

Departemen Kesehatan Republik Indonesia (2005) : Data lima tahunan penyakit menular langsung di Indonesia, DitJen PPM \& PPLP. Dep Kes RI, Jakarta)

Dhople AM (2000): Search of the newer antileprosy drug, Indian J Lepr, 72 (1), 5-20

Dinas Kesehatan Propinsi Sulawesi Selatan (2005): Data lima tahunan penderita kusta, Makassar, Sulawesi Selatan

Haanpaa M, Lockwood DNJ, Hietaharju A (2004) : Neuropathic pain in leprosy, Lepr Rev, 75, 7-18

Hatta M (2003) : Epidemiology of leprosy. Molecular, biological and immunological approach, Adv Exp Med Biol, 531, 269-278

Hietaharju A, Croft R, Alam R et al. (2000) : The existence of chronic neuropathic pain in treated leprosy, Lancet, 356, 1080-1081

Jacobson RR (1994) : Treatment, Hasting RC eds., Leprosy, 2nd ed., 317-349, Churchill Livingstone (Tokyo)

Louhenapessy AA (1979) : Community participation in assisting leprosy control in Indonesia, The Second International workshop on leprosy Control in AsiaKatmandu, Nepal, Oct, 11-14, Sasakawa Memorial Health Foundation, 53-60

Muchtar SV, Amiruddin MD, Yogi Y et al. (2005) : Profil bakteriologis dan histopatologis sebelum dan sesudah quadriple therapy pada penderita kusta multibasiler, Pada Kongres Nasional XI PERDOSKI, Jakarta, Juli

Muchtar SV, Bang PD, Fujimura T et al. (2006) : Preliminary study; latar belakang kejadian penyakit kusta di Sulawesi Selatan, Indonesia dengan analisa fisiologik, biokimiawi dan serologis pada keluarga dengan penderita kusta pada anak. BERKALA Penyakit Kulit dan Kelamin. Surabaya : Airlangga University Press. (In printed)

Pusat Pelatihan Kusta Nasional (PLKN) (2004) : Modul pelatihan juru dan wasor kusta se Indonesia, Makassar, Sulawesi Selatan

Schreuder PA, Liben DS, Wahjuni S et al. (2002) : A comparison of Rapid Village Survey and Leprosy Elimination Campaign, detection methods in two dis- 
trict of East Java, Indonesia, 1997/1998 and 1999/ 2000, Lepr Rev, 73(4), 366-375

Van Beers SM, Izumi S, Madjid B et al. (1994) : An epidemiological study of leprosy infection by serology and polymerase chain reaction, Int $\mathrm{J}$ Lepr Other
Mycobact Dis, 62(1), 1-9

World Health Organizations (1999) : Eliminate of leprosy, Int J Lepr Other Mycobact Dis, 67 (1), 65-69

(Received 2006.10.11; Accepted 2007.4.7) 


\title{
Leprosy situation in South Sulawesi, Indonesia
}

\author{
Sri Vitayani MUCHTAR, Yoshiko YANAGIDA, Masumi ENDOH and Yasuko YOGI
}

Jpn J Health \& Human Ecology, 73(3) 112-117, 2007

\section{和文抄録}

WHO が実施してきたハンセン病制圧対策は 2000 年度までに多くの国々で成果をあげた．インドネシア は国レベルでは制圧国の域に達しているが，州や地区レベルでは今なお高い有病率を示している，スラ ヴェシ島は 6 州のうち, 南スラヴェシ州を含む実に 5 州で 1.1 人 $/ 10,000$ 人以上の有病率を示し, 每年新 たな患者の発生が見られる公衆衛生上問題のある島である．南スラヴェシ州は 27 統治区の 22 統治区で平 均有病率は 2.3 人 10,000 人である. 加えて, 子供のハンセン病患者を $5 \%$ 以上抱える近年の現洗からは八 ンセン病制圧プログラムが成功しているとは言いがたい.ささに, WHO が推奨する MDT 治療, ハンセ ン病制圧プログラムのもとに行われている研究成果からもこの地域におけるハンセン病撲滅のための明快 な回答は得られていない. 南スラヴェシ州のハンセン病制圧にはさらに時間が必要である. 